\title{
ADVANCED DIFFERENTIAL INTERFEROMETRIC SAR TECHNIQUE A-DINSAR FOR THE STUDY OF LARGE LANDSLIDES
}

\author{
CLAUDIA MEISINA (*) \\ Nota presentata dal m.e. Cesare Perotti \\ (Adunanza del 22 gennaio 2015)\#
}

SuNTO. - Le grandi frane sono diffuse sia nelle Alpi che nell'Appennino; i movimenti osservati sono generalmente da estremamente lenti a lenti con qualche accelerazione occasionale; il crollo improvviso e parossistico di tutta la massa può avere conseguenze catastrofiche. Risulta difficile individuare correttamente i loro limiti e monitorare il loro stato di attività con strumenti tradizionali. La tecnica dell'interferometria SAR (Synthetic Aperture Radar) differenziale avanzata, A-DInSAR, è una tecnica di telerilevamento, basata su immagini radar satellitari per la misurazione del movimento del suolo. Si basa su immagini multitemporali SAR e consente la misura di spostamenti del terreno con una precisione millimetrica. Lo scopo di questo studio è applicare la tecnica A-DInSAR in alcune grandi frane nelle Alpi (Brenvetto, Rosone e Alpe Baranca) al fine di studiare l'efficacia della tecnica A-DInSAR nel loro studio e monitoraggio.

ABSTRACT. - Large landslides are widespread both in the Alps and in Apennines; the observed movements are generally from extremely slow to slow with some occasional acceleration; the sudden and paroxysmal collapse of the whole mass may have catastrophic consequences. They are also difficult to characterize in their boundaries and state of activity and to monitor with traditional tools. The Advanced Differential interferometric SAR (Synthetic Aperture Radar) technique, A-DInSAR, is a remote sensing technique, which is based on satellite radar imagery for the ground motion measurement. It is based on large stacks of SAR images and enables the measure of small displacement of the

(*) Department of Earth and Environmental Sciences, University of Pavia, Italy. E-mail: claudia.meisina@unipv.it

\# Nota pervenuta il 1 luglio 2018. 
ground with a millimetThe aim of this study is to apply the A-DInSAR technique in some large landslide in Alps (Brenvetto, Rosone and Alpe Baranca landslides) in order to study the effectiveness of the technique in their study and monitoring.

\section{INTRODUCTION}

The Vajont landslide event is considered the most disastrous rockslide ever to occur in European territory. It is one of the most examples of a natural disaster induced by human activity and it represents an important case history for scientists and researchers dealing with large rockslides and/or reservoir-induced slope failures.

Large landslides are widespread both in the Alps and in Apennines (Mortara \& Sorzana, 1987; Forlati et alii, 2001; Ambrosi \& Crosta, 2006); the observed movements are generally from extremely slow to slow (Cruden \& Varnes, 1996); they are quite regular with some occasional acceleration. Rapid and superficial phenomena are often associated and they result in significant direct and indirect damage. The sudden and paroxysmal collapse of the whole mass may have catastrophic consequences. They are also difficult to characterize in their boundaries and state of activity, to monitor with traditional tools due to their extension (landslides over $0.2 \mathrm{~km}^{2}$ ) and low rates of movement, which are close to the detection limit of traditional monitoring equipment (Notti et alii, 2013).

The Advanced Differential interferometric SAR (Synthetic Aperture Radar) technique, A-DInSAR, is a remote sensing technique, which is based on satellite radar imagery for the ground motion measurement. It is based on large stacks of SAR images and enables the measure of small displacement of the ground with a millimetric accuracy. This technique can be applied to large landslide study and monitoring due to:

1. The cost-effectiveness of the technique for wide-area applications (hundreds and thousands of $\mathrm{km}^{2}$ );

2. The high density of benchmarks (buildings, rock outcrops, etc..) (up to several hundred per $\mathrm{km}^{2}$ );

3. The use of "natural" benchmarks not requiring deployment and maintenance;

4. The possibility of geo-locating the benchmarks with a precision in the order of $1-5$ meters; 
5. The availability of the extremely valuable SAR images archive spanning about 30 years, which enables to carry out retrospective studies;

6. Regular revisiting time in the order of 20-40 days (up to 6 days with the new Sentinel-1 ESA mission).

In the last 20 years A-DInSAR techniques have undergone a strong development; Persistent Scatterer Interferometry (PSI) methods (e.g. PSInSAR ${ }^{\mathrm{TM}}$ Ferretti et alii, 2001), SqueeSAR ${ }^{\mathrm{TM}}$ (Ferretti et alii, 2011), small baseline subset - SBAS (Berardino et alii, 2002), SPN (Arnaud et alii, 2003), and coherent pixel techniques - CPT (BlancoSànchez, 2008), PSP-DIFSAR (Persistent Scatterers Pairs - Differential InSAR; (Costantini et alii, 2000), allowed to help the detection and monitoring of the very slow and extremely slow movements typical of many large landslides (Colesanti \& Wasowski, 2006; Farina et alii, 2006; Meisina et alii, 2006; Herrera et alii, 2009; Guzzetti et alii, 2009; Lauknes et alii, 2010; Yin et alii, 2010).

The aim of this study is to analyze the large landslide kinematics through specific case histories in Alps (Brenvetto, Rosone and Alpe Baranca landslides) with particular focus on spatial and temporal analysis of the movement.

\section{BRENVETTO LANDSLIDE}

The landslide of Brenvetto is located in Soana stream basin at the east boundary of Gran Paradiso massif. The landslide is geologically located in the Pennine Nappe, between Sesia-Lanzo zone and Gran Paradiso internal massif (Fig. 1). It is characterized by calc-schist and serpentine formation bedrock. The area is covered also by moraine quaternary deposits (Carraro et alii, 1995). The main element at risk is the road that connects the high Soana Valley with Orco valley and then the Torino plain.

The upper sector of the slope is affected by large DSGSD (Deep Seated Gravitational Slope Deformation) that does not show any particular evidence of movement except in the central part of the deformation, where a complex landslide was detected (Fig. 2). The complex landslide shows clear evidences of movement like trenches, scarps, a strongly fractured rock-mass and many debris flows derived from rock fall and rock mass disaggregation. 


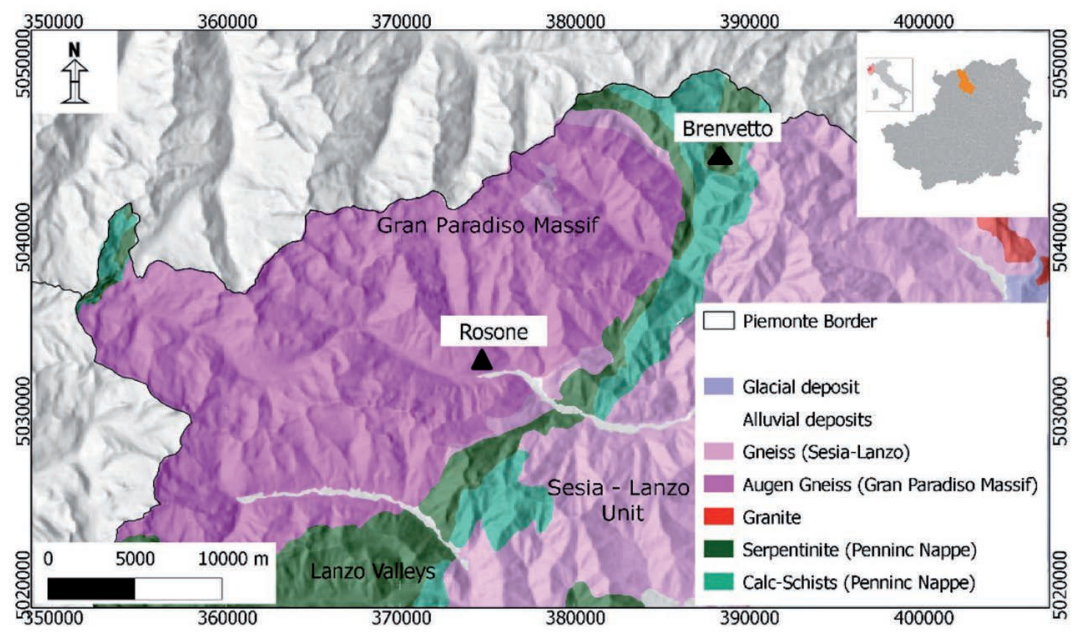

Fig. 1. Geological settings of Rosone and Brenvetto landslides.
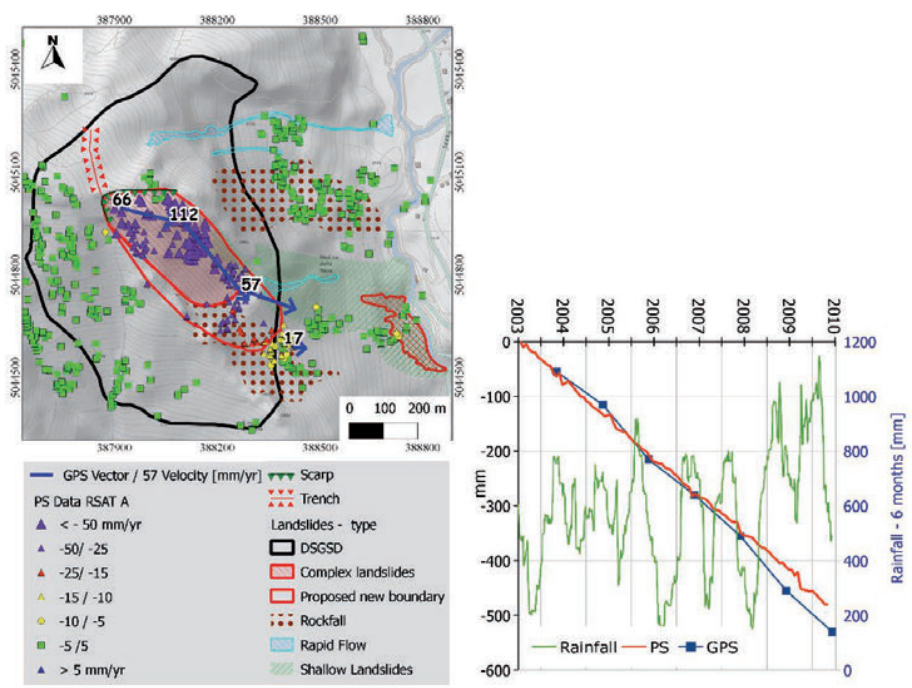

Fig. 2. Brenvetto Landslides. GPS data (2004-2011) and SqueeSAR data (2003-2009). In the graphic PS (RADARSAT ascending data) and GPS time series compared with 6 months cumulated rainfall.

In the lower sector of the slope widespread shallow landslides, debris flows can be noticed and at the toe of the slope erosion of Soana 
stream contributes to the general instability (Fig. 2). The landslide is monitored by ARPA Piemonte with 5 GPS at manual reading since 2004. The measurements made once at year showed a rate of movement that is up to $110 \mathrm{~mm} / \mathrm{yr}$ in the central sector of the complex landslide. The SqueeSARTM data derived from RADARSAT (2003-2009) ascending geometry show a very good numbers $(>20)$ and spatial distribution of targets PS/DS (Persistent Scatterer and Distributed Scatterer) on complex landslide. The rate and the spatial distribution of movement registered by PS/DS is almost the same of GPS measurements (Fig. 2).

The direction of the movement (from ESE to SE) is quite parallel with LOS ascending direction and about the $80 \%$ of the movement can be detected. It is not possible to resolve the north/south component of the movement due to the few descending data available. The PS/DS data suggested potential enlargement of the complex landslide boundaries to include also some downslope sectors and to update the state of activity: now the landslide is classified as active. The time series of PS and GPS (Fig. 2) data show a linear and constant trend of deformation that seems not influenced by rainfall or snow melting. However a small acceleration of the movement was detected by GPS, and also by some PS in 2008/2009. This can be related to the rainy period started in May 2008. Due to the high velocity registered it is possible that some errors related to phase unwrapping (movement greater than $\lambda / 4$ between two consecutive acquisitions) should be occurred.

\section{Rosone LANDSLIDES}

The Rosone landslide is located in the NW Italian Alps in the Orco Valley and it is classified as DSGSD.

The landslide affects the penstock of the near hydroelectric central and in case of collapse may create a dam in the Orco river and an interruption of the road that connects the upper part of the valley with the plain. For these reasons the landslide was well studied by many authors (Forlati et alii, 2001; Pisani, 2010; Ramasco et alii, 1989) that provide to asses the geomorphological, hydrogeological and mechanical settings and they try to model the possible evolution.

The Orco Valley is located in the central part of the Gran Paradiso Massif. This complex belongs to the Upper Pennine Units (Pennine Nappe System) and it consists of a composite crystalline base- 
ment and a Permo-Liassic cover (Fig. 1). Rosone landslide is modelled on the Augen Gneiss Complex. The geological-structural configuration of the studied area is relatively simple: granite and augen gneiss crop out. The rock mass is characterized by several alpine ductile deformation phases. The main schistosity is affected by the periclinal orientation of the massif, which, in this area, displays an aver-age dip direction of about $150^{\circ}$, with $35^{\circ}$ dip (Regione Piemonte, 1996). The brittle structural attitude is defined by three main discontinuity systems: a KS system parallel to main schistosity (SR) and two sub-vertical lineaments corresponding to E-W and N-S striking normal fault conjugate system.

The landslide of Rosone is located on a slope affected by large DSGSD but only the sector of Rosone/Bertodasco has high deformation and instability. The western sector of DSGSD (Ronchi village) presents less evidence of deformations and the movement is more related to shallow debris and colluvium instability.

Considering the most active part of the DSGSD, the Bertodasco area, the geomorphological and the structural analysis joined with monitoring data allowed to detect three main sectors with different rock mass evolution and movement (Fig. 3).

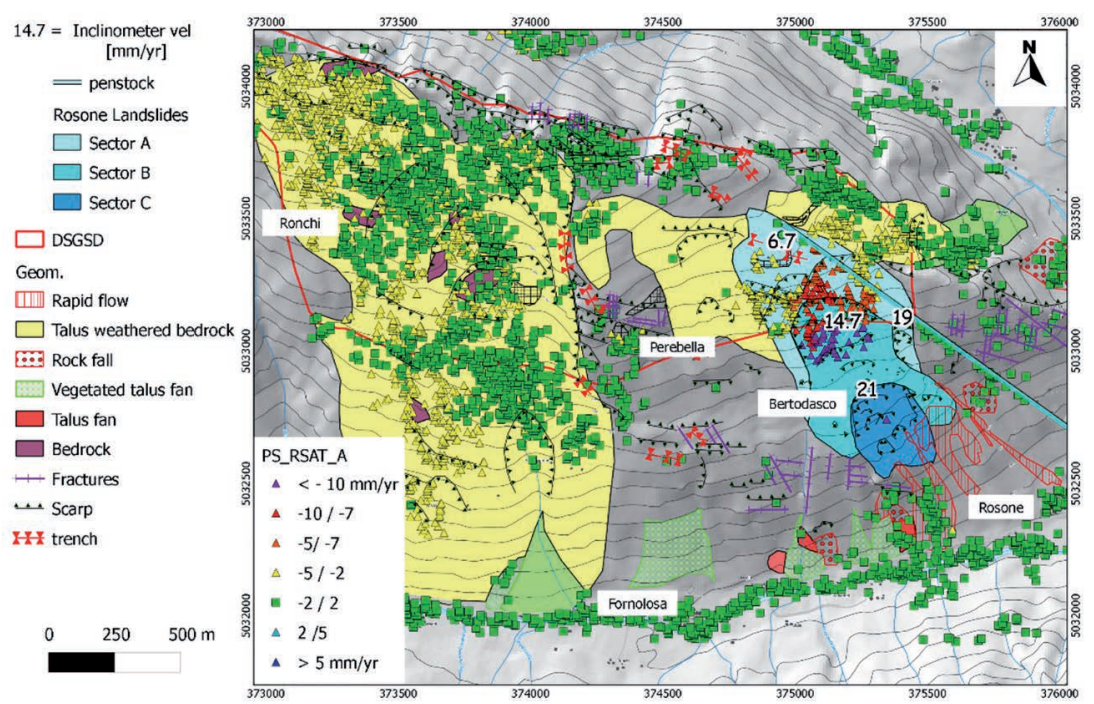

Fig. 3. Rosone geomorphological map and PS data (SqueeSAR, RADARSAT Ascending). 
Sector A. It corresponds to the upper part of slope. This is the less weathered rock mass, however many trenches and scarps can be detected. The movement is generally weak and sliding surface is between 30 and $75 \mathrm{~m}$.

Sector B. It is in the central part of deformations. The rock mass is rather weathered with completely disarticulated rock block, scarps and the presence of many debris. The sliding surface can be identified $46 \mathrm{~m}$ depth.

Sector C. It is in the bottom part of the slope and it is the most weathered sector, the rock mass is completely disarticulated. The depth of sliding surface is $39 \mathrm{~m}$. This sector is also affected by rock fall and debris flow. In the 1953 a strong reactivation of the movement caused severe damages to Bertodasco village and the inhabitants were evacuated.

The A-DInSAR analysis it is possible only in the sector A and B where a good density of data is available especially with RADARSAT data. The sector $\mathrm{C}$ has a wide forest coverage and too fast movement and only 1 PS is present.

- The sector A presents weak movements $(5 \mathrm{~mm} / \mathrm{yr})$ in the eastern part and moderate movements (up to $10 \mathrm{~mm} / \mathrm{yr}$ ) in the western part that affect the penstock. The movements progressively increase from upslope to downslope.

- The sector B is characterized by moderate movements from 10 to 20 $\mathrm{mm} / \mathrm{yr}$. It is possible to see that a scarp borders a sub-sector with major movement.

- The sector C does not have significant PS data due to the vegetation coverage and the high movements that probably cause unwrapping problems. However, the only PS in the sector $\mathrm{C}$ recorded a velocity of $25 \mathrm{~mm} / \mathrm{yr}$. The GPS and optical measurements show a velocity from 45 up to $130 \mathrm{~mm} / \mathrm{yr}$.

The time series of PS RADARSAT data (Fig. 4) show a small decrease of the movement in 2005-2007, probably related to a drier period. The movement can be considered as constant and linear. Other monitoring systems show some acceleration after October 2000 flood especially in the sector "C" but no PS data are available for this period.

The ERS data (1992-2001) present a very low density of data especially for ascending geometry, however the few PS on the landslide confirm the same rate of velocity of RADARSAT.

The projection of the velocity of PS data was made on the mean 
dip direction schistosity of the rock mass and from the results of GPS measurements. The direction of the movement is between SE and SSE $\left(150^{\circ}-170^{\circ}\right)$. The ascending geometries can detected about the $60 \%$ of real movement.

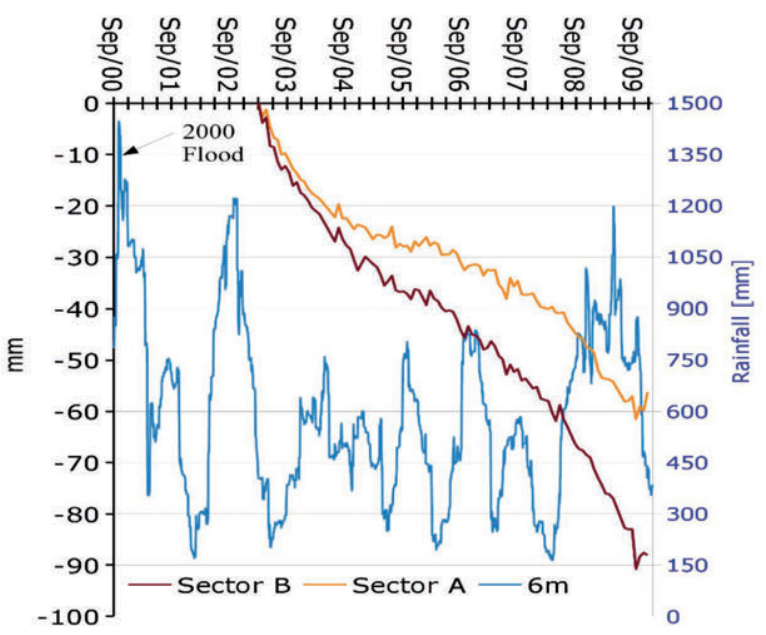

Fig. 4. Rosone Landslide. PS Time series (2003-2009 RADARSAT descending data) of the sectors $A$ and B compared with 6 months (6m) cumulated rainfall (2000-2009).

The combination of ascending and descending geometries allowed to resolve the vertical and E-W component of the movement. The results (up to $6 \mathrm{~mm} / \mathrm{yr}$ toward East, and $10 \mathrm{~mm} / \mathrm{yr}$ to down) are in a very good agreement with the other monitoring instruments.

\section{Alpe Baranca DSGSD}

The Alpe Baranca DSGSD is located in the upper Mastallone stream basin near the village of Fobello. The PS/DS data is the only monitoring system available on this landslide.

Excepted an alpine hut there are no anthropic elements at risk however the landslide is interesting because after October 2000 flood a large fracture appeared in the upper part of the slope as evidence of a great acceleration of the movement of the whole mass. 
This area is geologically located inside the Sesia-Lanzo zone, with bedrock of diorite-kinzigite and mica-schist. The main tectonic lineament are oriented SW-NE (Fig. 5).
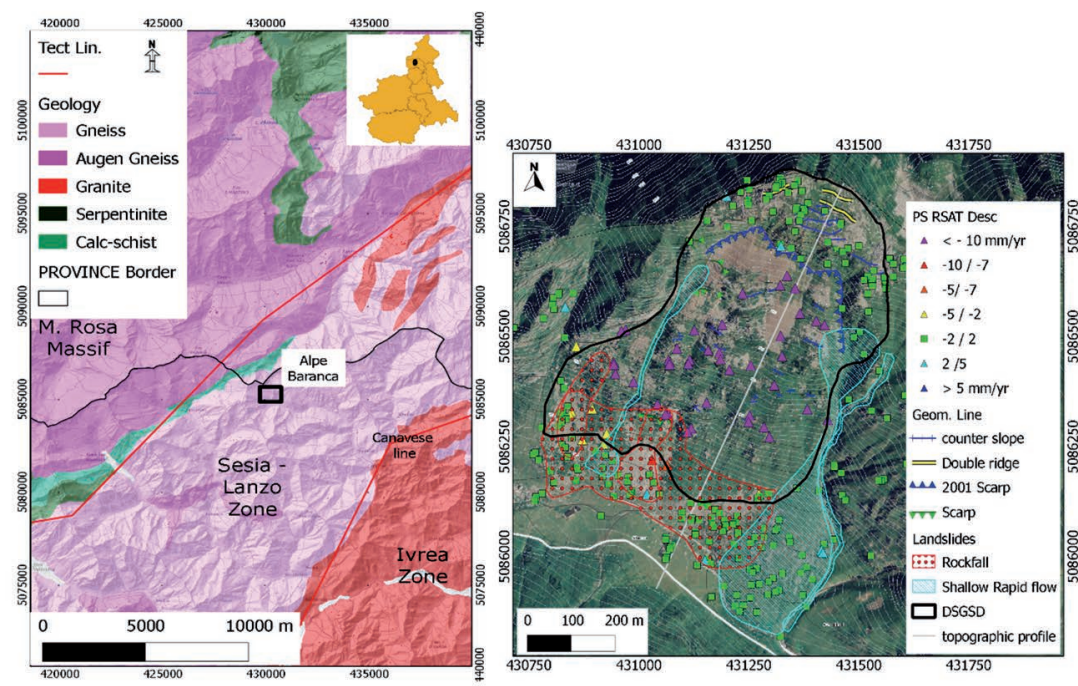

Fig. 5. Alpe Baranca Geological settings and Main Geomorphological elements and RADARSAT descending data.

The DSGSD is located on a slope with SW orientation from 2300 to $1600 \mathrm{~m}$ a.s.l.

The deformation presents three main sectors (Maffeo \& Zanottelli, 2008):

- The upper sector with a steep slope is characterized by weak weathered bedrock but with great evidence of deformations like double ridge and counter slope, areas affected by rockfall. The PS/DS data do not show any particular movement in this sector.

- The central sector is the area where bedrock is mostly disarticulated with many scarps, counter slope, bulged profiles and many debris deriving from rockfall. After the 2000 flood this entire sector moved of some meters and at the edge of upper sector a large scarp appeared in 2001 spring after snow melting (Fig. 5). The scarp shows a displacement up to $6 \mathrm{~m}$ in the central part.

The ERS data (1992-2000) (pre-failure) identified a movement from -5 up to $-15 \mathrm{~mm} / \mathrm{yr}$ measured along descending LOS. The 
RADARSAT data during the period 2003-2009 (post-failure) measured the same rate of velocity (average Vlos $-13 \mathrm{~mm} / \mathrm{yr}$ ). The analysis of time series allowed also to discover a phase unwrapping problems in 2004 caused by a gap of some images. With the correction of this unwrapping problem the average Vlos can be estimated to $-20 \mathrm{~mm} / \mathrm{yr}$.

Considering an average slope of $34^{\circ}$ and a slope orientation of $205^{\circ} \mathrm{N}$ azimuth the average velocity projected along the slope is about $-50 \mathrm{~mm} / \mathrm{yr}$ for the period 2003-2009.

By combining ascending and descending geometries it was possible to extract East-West and vertical component of the velocity. The vertical component presents greater values than E-W component (up to 10 toward West), the North-South component cannot be calculated but is probably greater than E-W due to SSW slope orientation.

The analysis of time series do not show any particular trend and the movement can be considered linear (Fig. 6). It is possible to appreciate however that in the first years of measurements (2003-2005) the velocity had higher values $(-25 /-27 \mathrm{~mm} / \mathrm{yr}$, along LOS $)$ then slowed to $-16 /-18 \mathrm{~mm} / \mathrm{yr}$. This trend is compatible with deceleration after the events of 2000-2001.

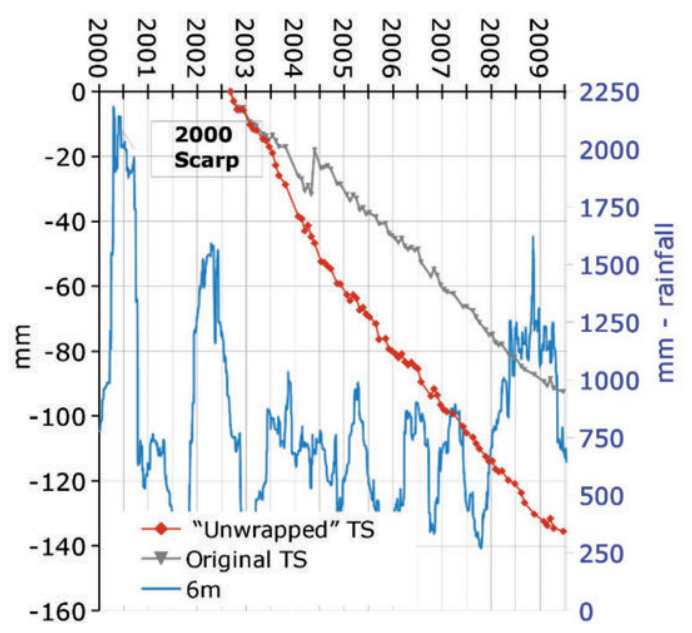

Fig. 6. Alpe Baranca DSGSD: original and "unwrapped" Time series (2003-2009) compared with and 6 months cumulated rainfall (2000-2009).

Note the bigh peak of rainfall occurred in winter 2000-2001. 
- The third sector is located at the toe of the slope and it is probably not affected by DSGSD. In this sector we have the presence of talus cone and debris deriving from rockfall. A large fan deriving from rapid flow accumulation is located in the SE sector of the slope. If the velocity and the slope profile are compared a quite good match between geomorphology and velocity detected by SAR data can be appreciated.

\section{CONCLUSiOnS}

The analysis of large $\left(>0.2 \mathrm{~km}^{2}\right)$ slow moving landslides (DSGSD, complex slides, slow flow and roto-traslational slides) with PSI data showed good results, considering the traditional limitations of PSI technique.

The A-DInSAR data were useful to increase the knowledge about landslide kinematics and to integrate information coming from other monitoring systems.

The Brenvetto landslide, in the Soana Valley, is an example of good integration of A-DInSAR and GPS data; both spatial and temporal distributions of the movement (time series) agree and well match the geomorphological evidence.

The Rosone Landslides is one of the most studied landslides in western Alps, due to catastrophic consequence of a collapse that may affect the penstock. In this case the PSI data confirm the already dense and heterogeneous monitoring system network. Due to the benefits in density and for the easiness in data acquisition and storage over large areas, it was decided to integrate and largely replace the old monitoring system with a regular A-DInSAR analysis (every year) in order to follow the evolution of the phenomenon for civil protection purposes.

Generally the monitoring data showed that the DSGSD affecting a slope are generally without movement, while the large landslides, which are related to the main DSGSD, are active and potentially dangerous.

On the opposite for the Alpe Baranca DSGSD the role of ADInSAR coupled with geomorphological analysis was fundamental because it was the only available monitoring system. ERS (1992-2000) and RADARSAT (2003-2009) data measured a strong acceleration (some meters) after October 2000 flood and a fracture appeared in the 
upper part of the slope. PS time series confirm the movement of this sector before and after the paroxysm event but with rate of movement constant and relatively low. This can be an evidence that a good PS coverage allows to detect landslides characterized by extreme slow movement that sometime can have potentially hazardous acceleration when extreme trigger factors occur.

\section{ACKNOWLEDGMENTS}

The authors are grate to: TeleRilevamento Europa (TRE) that processed the SAR data; ARPA Piemonte that provides information for local site, SAR and other monitoring system data.

\section{REFERENCES}

BERARDINO P., FORNARO G., LANARI R., \& SANSOSTI E. (2002). A new algorithm for surface deformation monitoring based on small baseline differential SAR interferograms. IEEE Transactions on geoscience and remote sensing, 40(11), 2375-2383.

BLANCO-SANCHEZ P., MALLORQUÍ J.J., DUQUE S., \& MONELLS D. (2008). The coherent pixels technique (CPT): An advanced DInSAR technique for nonlinear deformation monitoring. In Earth Sciences and Mathematics (pp. $1167-$ 1193). Birkhäuser Basel.

CARRARO F., FORNO M.G. \& BOCCA P.C. (1995). Fenomeni gravitativi nell'alta Val Soana (Torino). Mem. Soc. Geol. It., 50, 45-58.

COLESANTI C \& WASOWSKI J. Investigating landslides with space-borne Synthetic Aperture Radar (SAR) interferometry. ENG. GEOL., 88: 173-199.

COSTANTINI M., IODICE A., MAGNAPANE L. \& PIETRANERA L. (2000). Monitoring terrain movements by means of sparse SAR differential interferometric measurements. In Proc. IGARSS 2000, Honolulu, USA, pp. 3225-3227.

CRUDEN D.M. \& VARNES D.J. (1996). Landslide types and processes in: Landslides, investigation and mitigation, Special Report 247, (ed. A. K. Turner \& R. L. Schuster), Transportation Research Board, National Research Council; National Academy Press, Washington, D.C.; pp. 36-75.

FARINA P., COLOMBO D., FUMAGALII A., MARKS, F. \& MORETTI S. (2006). Permanent Scatterers for landslide investigations: outcomes from the ESASLAM project Engineering Geology, 88 (3-4), pp. 200-217.

FERRETTI A., PRATI C. \& ROCCA, F. (2001). Permanent Scatterers in SAR interferometry. IEEE T GEOSCI REMOTE 39(1):8-20.

FERRETTI A., FUMAGALII A., NOVALI F., PRATI C., ROCCA F. \& RUCCI, A. 
(2011). A New Algorithm for Processing Interferometric Data-Stacks: SqueeSAR. IEEE T GEOSCI REMOTE, vol. 49, no. 9, pp. 3460-3470.

FORLATI F., GIODA G. \& SCAVIA C. (2001). Finite element analysis of a deep seated slope deformation. In printing: Rock Mech. and Rock Eng.

FORLATI F., BROVERO M. \& CAMPUS S. (1995). Alcune considerazioni sulle deformazioni gravitative profonde di versanti inerenti il territorio piemontese. Atti $2^{\circ}$ incontro internazionale dei giovani ricercatori in geologia applicata, Peveragno (Cuneo), 75-81.

GUZZETTI F., MANUNTA M., ARDIZZONE F., PEPE A., CARDINALI M. \& ZENI G. (2009). Analysis of ground deformation detected using the SBASDInSAR technique in Umbria, Central Italy. Pure and Applied Geophysics, 166, pp. 1425-1459.

HERRERA G., GARCÍA-DAVALILLO J.C., MULAS J., COOKSLEY G., MONSERRAT O. \& PANCIOLI V. (2009). Mapping and monitoring geomorphological processes in mountainous areas using PSI data: Central Pyrenees case study. NAT HAZARD EARTH SYS, 9:1587-1598.

LAUKNES T.R., PIYUSH SHANKER A., DEHLS J.F., ZEBKER H.A., HENDERSON I.H.C. \& LARSEN Y. (2010). Detailed rockslide mapping in northern Norway with small baseline and persistent scatterer interferometric SAR time series methods. Remote Sensing of Environment, Volume 114, Issue 9, 15 September 2010, Pages 2097-2109, ISSN 0034-4257, 10.1016/j.rse.2010.04.015

MAFFEO \& ZANOTELELLI (2008). Movimento franoso dell'Alpe Baranca - Carta Geomorfologica. Municipality of Fobello Internal Report. ARPA Piemonte archive.

MEISINA C., ZUCCA F., FOSSATI D., CERIANI M. \& ALIIEVI J. (2006). Ground deformation monitoring by using the Permanent Scatterers Technique: The example of the Oltrepo Pavese (Lombardy, Italy) Engineering Geology, 88 (3-4), pp. 240-259.

MEISINA C., ZUCCA F., NOTTI D., COLOMBO A., CUCCHI A., SAVIO G., GIANNICO C. \& BIANCHI M. (2008). Geological interpretation of PSInSAR data at regional scale. Sensors 2008, Volume 8(11), pp. 7469-7492.

MORTARA G. \& SORZANA P.F. (1987). Fenomeni di deformazione gravitativa profonda nell'arco alpino occidentale italiano. Considerazioni litostrutturali e morfologiche. Boll. Soc. Geol. It., 106, 303-314.

NOTTI D, MEISINA C., COLOMBO A., LANTERI L. \& ZUCCA F. (2013). Studying and monitoring large landslides with persistent scatterer data. Italian Journal of Engineering Geology and Environment - Book Series (6), 349-360, DOI: 10.4408/IJEGE.2013-06.B-33, ISBN 978-88-95814-96-4.

PISANI G., CASTELLI M. \& C. SCAVIA C. (2010). Hydrogeological model and hydraulic behaviour of a large landslide in the Italian Western Alps. Nat. Hazards Earth Syst. Sci., 10, 2391-2406.

RAMASCO M., STOPPA T. \& SUSELLA G. (1989). La deformazione gravitativa profonda di Rosone in Valle dell'Orco. Bollettino della Società Geologica Italiana, 108(03), 1989, pp. 401-408.

REGIONE PIEMONTE \& UNIVERSITÈ J. FOURIER (EDS.) (1966). La frana di 
Rosone, Valle Orco - In: Rischi Generati da Grandi Movimenti Franosi, Programme INTERREG I Italy-France: 144-177.

YIN Y., ZHENG W., LIU Y., ZHANG J., \& LI X. (2010). Integration of GPS with InSAR to monitoring of the Jiaju landslide in Sichuan, China. Landslides, 7, 359-365. 